\title{
Azerbejdżan w reportażach tureckich literatów z lat sześćdziesiątych XX wieku
}

ziz Nesin, znany turecki satyryk, który w czerwcu 1965 roku zaproszony przez
Związek Pisarzy Sowieckich uczestniczył wraz z dwoma innymi popularnymi
tureckimi pisarzami (Melihem Cevdetem Andayem i Yaşarem Kemalem) w kongresie
pisarzy azjatyckich i afrykańskich w Moskwie, a przy okazji wizyty w ZSRR miał również możliwość pojechać do Baku, tak skomentował ten fakt w reportażu prasowym: „Jesteśmy pierwszymi tureckimi literatami, nie licząc Nazıma Hikmeta ${ }^{251}$, którzy po niemal 40 latach przyjeżdżają z Turcji do Azerbejdżanu"252.

Rzeczywiście, odkąd Azerbejdżan w 1920 roku został włączony do Związku Radzieckiego jako Azerbejdżańska Socjalistyczna Republika Radziecka, stosunki (nie tylko literackie) pomiędzy tymi dwoma państwami zostały praktycznie zerwane. Nigâr Nagıyeva, autorka książki 1990’dan Günümüze Türkiye ve Azerbaycan Edebiyatlarının Karşılıklı Etkileşimi [Interakcje między literaturą turecką i azerbejdżańską po 1990 roku] zauważa, że najważniejszym okresem w stosunkach turecko-azerbejdżańskich były lata 1905-20. Powołując się na słowa innych badaczy tego tematu podkreśla, że Turcy i Azerbejdżanie, wywodzący się z jednej wspólnoty etnicznej, przez dhugie lata „żyli pod wspólnym dachem” i mimo iż na różnych etapach swej historii byli rozdzielani i włączani w skład innych organizmów państwowych, to zawsze elementem łączącym oba narody była wspólnota kulturowa. ${ }^{253}$ Przełom XIX i XX wieku to czas wielkich ruchów narodowowyzwoleńczych i powolnego upadku imperiów wielonarodowościowych; to czas, kiedy wciąż jeszcze realna wydaje się realizacja idei Wielkiego Turanu. W duchu panturkizmu kwitną więc kontakty literackie turecko-azerbejdżańskie, nie tylko na płaszczyźnie ideologicznej, ale przejawiające się również w zapoznawaniu się z osiągnięciami literackimi obu narodów i bezpośredniej wymianie doświadczeń literackich. Kontakty te zamierają stopniowo po 1920 roku, nie tylko z powodu narastającej sowietyzacji Azerbejdżanu, ale również trudnej sytuacji politycznej

\footnotetext{
${ }^{251}$ Nazım Hikmet (turecki poeta, komunista, aresztowany w Turcji za działalność polityczną, od 1951 roku przebywający na emigracji w ZSRR, zmarł w Moskwie w 1963 roku) kilkukrotnie odwiedził Baku: w 1927, 1957 i 1960 roku. Jego wiersze i sztuki teatralne wydawano w Azerbejdżanie (podobnie jak i w innych republikach radzieckich), a azerbejdżańscy pisarze wzorowali się na jego twórczości, bądź też wspominali go w swych utworach. Por. N. Nagıyeva, 1990'dan Günümüze Türkiye ve Azerbaycan Edebiyatlarının Karşıllklı Etkileşimi, Hiperlink Yayınları, İstanbul 2017, s. 41.

252 A. Nesin, Gelbden Gelbe Yol Vardır, "525-ci qəzet", 30.05.2009, s. 3. Cyt. za: Z. Aliyeva, TürkiyeAzerbaycan Edebi İlişkilerinde Selef ve Halef Yazarlar: Mirza Fethali Ahundzade ve Anar Rizayev, „Atatürk Üniversitesi Sosyal Bilimler Enstitüsü Dergisi” 2015, nr 19 (1), s. 2017. Wszystkie tłumaczenia cytatów z języka tureckiego, o ile nie podano inaczej, są autorstwa Sylwii Filipowskiej.

${ }^{253}$ N. Nagiyeva, op.cit., s. 9.
} 
Turków, walczących w wojnie wyzwoleńczej o narodową suwerenność. Wprawdzie jeszcze w 1925 roku Turcja i ZSRR podpisały pakt o przyjaźni i nieagresji, jednak w rzeczywistości nie utrzymywano kontaktów dyplomatycznych czy kulturalnych, szczególnie w czasach stalinowskich $^{254}$. Związek Radziecki stał się krajem hermetycznym, praktycznie niedostępnym dla przybyszów z zewnątrz, a przez to tajemniczym i pociągającym. Na jego temat krążyły różne, często sprzeczne w zależności od orientacji politycznej autora, opinie. Dobrze pokazują to słowa Şevketa Rado:

„W ciągu ostatniego półwiecza wiele napisano na temat Rosji i wciąż się o niej pisze. Ale Rosja jest specyficznym krajem, a ustrój komunistyczny, który w niej panuje od rewolucji 1917 roku, ma wielu zagorzałych zwolenników i wielu równie zaciekłych przeciwników. I to oni piszą na temat Rosji. Według zagorzałych zwolenników komunizmu wszystko w Rosji jest w najwyższym stopniu dobre, a według jego zaciekłych przeciwników - wszystko jest w najwyższym stopniu złe. Patrząc na tak sprzeczne opinie, można dość do wniosku, że cały świat nie zdołał ujrzeć prawdziwego oblicza Rosji sowieckiej, poznać jej taką, jaka jest w rzeczywistości, i dotrzeć do wiarygodnych sądów - w przypadku tych, którzy twierdzą, że wydają obiektywne opinie, trzeba jeszcze sprawdzić, czy i w jakim stopniu są bezstronni" 255 .

Dopiero w latach sześćdziesiątych ZSRR zaczęło otwierać się na świat, a pretekstem do tego stały się obchody pięćdziesiątej rocznicy rewolucji październikowej. Z tej okazji „zaczęto zapraszać pisarzy, artystów, dziennikarzy i polityków z różnych krajów Wschodu i Zachodu"256. Z zaproszeń skorzystali również i tureccy intelektualiści, stąd w latach sześćdziesiątych odnaleźć można liczne przykłady tureckiej literatury reportażowej bądź quasi-reportażowej na temat różnych regionów wchodzących w skład ZSRR, w tym Azerbejdżanu.

\section{Cel i okoliczności podróży tureckich literatów do Azerbejdżanu w latach sześćdziesiątych $\mathrm{XX}$ wieku}

Azerbejdżan był chętnie pokazywany zagranicznym gościom przez władze ZSRR jako bogata i uprzemysłowiona część kraju. Turcy mieli również własne, „narodowe” powody, które skłaniały ich do odwiedzenia Azerbejdżanu (oraz innych republik radzieckich, w których większość populacji stanowili przedstawiciele narodów turkijskich): chcieli poznać prawdę o losie współbraci pozostających pod rządami Sowietów oraz sprawdzić, jak funkcjonuje komunizm w społeczeństwach turkijskich.

Jako materiał badawczy wybrano reportaże sześciu tureckich literatów. Zostaną one przedstawione pokrótce, z uwzględnieniem elementów niezbędnych do dalszej analizy, takich jak cel i czas podróży czy poglądy polityczne autora. Melih Cevdet Anday (1915-2002) to znany turecki poeta (współinicjator ruchu poetyckiego Garip), autor sztuk teatralnych, powieści i esejów, a także niespełna dwustustronicowego utworu reportażowego,

\footnotetext{
${ }^{254}$ Ibidem, s. 28.

${ }^{255}$ Ş. Rado, 50 Yllında Sovyet Rusya, Doğan Kardeş Matbaacılık Sanayii A.Ş., İstanbul 1968, s. 6.

${ }^{256}$ B. Asıltürk, Edebiyatın Kaynă̆ı Olarak Seyahatnameler, „Turkish Studies” 2009, nr 4, s. 986.
} 
zatytułowanego Sovyet Rusya, Azerbaycan, Özbekistan, Bulgaristan, Macaristan [Rosja sowiecka, Azerbejdżan, Uzbekistan, Bułgaria, Węgry]. Anday, zdeklarowany zwolennik socjalizmu, opisał $\mathrm{w}$ niej między innymi swe wrażenia $\mathrm{z}$ trwającej około trzech tygodni podróży do ZSRR, której głównym punktem było uczestnictwo w kongresie pisarzy azjatyckich i afrykańskich w Moskwie w czerwcu 1965 roku. W Azerbejdżanie spędził zaledwie kilka dni, a jego towarzyszami podróży byli dwaj inni wybitni (i również lewicujący) tureccy literaci: satyryk Aziz Nesin i powieściopisarz Yaşar Kemal, którzy nie napisali dłuższych relacji reportażowych $\mathrm{z}$ tego pobytu.

Praktycznie w tym samym czasie odwiedził ZSRR Metin Toker (1924-2002), dziennikarz i pisarz, założyciel czasopisma i wydawnictwa „Akis”, prezes Stowarzyszenia Dziennikarzy Ankarskich, a prywatnie zięć İsmeta İnönü, drugiego prezydenta Republiki Turcji. Mimo otwarcie wyrażanej niechęci do komunizmu ${ }^{257}$, został zaproszony przez Związek Dziennikarzy ZSRR i wyjechał wraz z żoną na piętnastodniową wycieczkę. W Azerbejdżanie spędzili trzy dni w lipcu 1965 roku. Swe wrażenia Metin Toker opisywał praktycznie na bieżąco w tygodniku „Akis”, począwszy od numeru 578, datowanego na 17 lipca 1965 roku. Cykl jego reportaży pt. Rusya [Rosja], ukazujących się w kolejnych numerach czasopisma w rubryce „Dış Geziler” [Wycieczki zagraniczne], został następnie w 1966 roku wydany w formie książkowej jako Rus Geldi Aşka Rus'un Aşkı Başka [Rosjanin zapałał miłością, ale co to za miłość].

Na tle innych relacji reportażowych, dotyczących Azerbejdżanu, wyróżnia się Sovyet Rusya Imparatorluğu [Imperium Rosji Sowieckiej] Sameta Ăgaoğlu (1909-1982). Ten literat, prawnik i jednocześnie polityk (w latach 1950-60 był posłem $\mathrm{z}$ ramienia centroprawicowej Partii Demokratycznej, a lata 1960-64 spędził w więzieniu) urodził się w Baku, jako syn Ahmeta Ağaoğlu, azerbejdżańskiego polityka i dziennikarza, który wyemigrował do Stambułu po rewolucji młodotureckiej. Dwumiesięczny wyjazd do ZSRR, którego oficjalnym powodem było przygotowanie cyklu reportaży dla czasopisma „Son Havadis", a przede wszystkim kilkudniowy pobyt w Azerbejdżanie w sierpniu 1966 roku, były rodzajem podróży sentymentalnej śladami rodziców. Podróżując wraz z żoną samochodem był nieco bardziej niezależny niż inni reportażyści - mógł między innymi odwiedzić Karabach, miejsce urodzenia rodziców.

Uzak Komşu Rusya'dan Gezi Notları [Zapiski z podróży do naszego dalekiego sąsiada, Rosji] to pokłosie trzytygodniowej dziennikarskiej podróży İlhana Selçuka (19252010). Z wykształcenia prawnik, z zawodu dziennikarz współpracujący z najważniejszymi tureckimi dziennikami tj. „Akşam”, „Vatan” i „Cumhuriyet”, otwarcie prezentował on lewicowe poglądy, za które był prześladowany m.in. po przewrocie wojskowym z 1971 roku. Powodem jego wyjazdu do ZSRR było szukanie odpowiedzi na pytanie, w jakim kierunku powinna rozwijać się Turcja. W Azerbejdżanie spędził kilka dni w grudniu 1966 roku.

Musiała istnieć w Turcji potrzeba czytania na temat Rosji sowieckiej, skoro aż czterech uczestników delegacji premiera Süleymana Demirela do ZSRR we wrześniu 1967 roku wydało książki o charakterze reportażu (Mehmet Turgut, Şevket Rado, Bedii Faik,

\footnotetext{
${ }^{257} \mathrm{Na}$ początku cyklu swych reportaży Metin Toker przytacza słowa, których użył w rozmowie z jakimś wpływowym urzędnikiem w Rosji: nie boi się komunizmu, tylko go nie lubi. (M. Toker, Dış Geziler: Rusya, „Akis” 1965, nr 578, s. 5).
} 
Yılmaz Çetiner). W niniejszym artykule ze względu na wyróżniające się walory literackie, omówione zostaną dwie z nich. Şevket Rado (1913-1988), to bardzo ceniony w Turcji pisarz, dziennikarz i wydawca. Jego zaledwie osiemdziesięciopięciostronicowa książka 50. Yılında Sovyet Rusya [Rosja Sowiecka w 50 roku istnienia] jest rzadkim przykładem próby zachowania obiektywnego spojrzenia na ZSRR i komunizm, w czym pomógł z pewnością brak zaangażowania politycznego autora. Z kolei Mehmet Turgut (1929-2009) był czynnym politykiem, działającym w centroprawicowej Partii Sprawiedliwości, przewodzonej przez Süleymana Demirela. Pokłosiem jego podróży do ZSRR jako członka delegacji jest dwustustronicowa książka Taşkent'e Doğru. Rusya Notları [W stronę Taszkientu. Notatki z Rosji], zaskakująca wysokim poziomem literackim. Obaj pisarze w Azerbejdżanie spędzili zaledwie dwa dni.

Okoliczności podróży tureckich literatów do Azerbejdżanu w latach sześćdziesiątych są bardzo do siebie podobne i z pewnością wpływają na postrzeganie, a następie opis tego kraju. Po pierwsze, są to krótkie, kilkudniowe wycieczki przy okazji wizyty w ZSRR, przy czym wizyty te też są krótkie (najczęściej dwutygodniowe; najdłużej, bo aż 2 miesiące spędził w Związku Radzieckim Samet Ağaoğlu), a bardzo intensywne (przykładowo, Metin Toker wraz z żoną w ciągu 15 dni odwiedził Moskwę, Baku, Soczi, gruziński Kaukaz, Petersburg zwany wówczas Leningradem, Irkuck, Brack i wrócił do Moskwy. W ogólnym rachunku należy też wziąć pod uwagę duże odległości - sam przelot z Petersburga do Irkucka zajął im 13 godzin). Po drugie, podróżni zwiedzają na ogół tylko Baku i jego najbliższe okolice: przede wszystkim Sumgait, przemysłowe miasto nad Morzem Kaspijskim, założone przez Sowietów i pokazywane chętnie gościom jako radzieckie miasto modelowe, a także ewentualnie położone nieco dalej od Baku Neft Daşları, osiedle wybudowane na morzu w celu eksploatacji ropy naftowej. Obie te okoliczności sprawiają, że z czysto organizacyjnych powodów Turcy tylko powierzchownie mogą zapoznać się z sytuacją w Azerbejdżanie i często mają tego świadomość, a mimo to pragną przekonać czytelnika o swoim prawie do występowania $\mathrm{w}$ roli eksperta. W tym celu niejednokrotnie wypowiadają się o sytuacji w całym Azerbejdżanie, mimo iż widzieli tylko niewielki jego skrawek, niekoniecznie reprezentatywny względem całości. Takie metonimiczne podejście (pars pro toto) jest niewątpliwie celowo stosowanym zabiegiem retorycznym (nie tylko $\mathrm{w}$ stosunku do Azerbejdżanu, ale całego ZSRR), a reportażyści starają się na różne sposoby usprawiedliwić jego użycie. Samet Ağaoğlu używa w tym celu metafory lotu ptaka nad lasem: jego zdaniem, być może spacer po lesie pozwala na dostrzeżenie ukrytych tu i ówdzie szczegółów, ale poznanie rozległego terenu $\mathrm{w}$ tak drobiazgowy sposób zajęłoby długie lata. Tymczasem przyjrzenie się, choćby krótko i z lotu ptaka, większym połaciom kraju pozwala poczuć panującą tam atmosferę. Także Şevket Rado przyznaje, że jedenaście dni to za mało, by poznać tak olbrzymi kraj jak Związek Radziecki, po czym konstatuje zdroworozsądkowo: „Teraz wiem przynajmniej trochę na temat Rosji, o której do wczoraj nie wiedziałem nic. I to właśnie postaram się opisać, 258 .

Trzecim, bodajże najistotniejszym, czynnikiem, wpływającym na okoliczności podróży do ZSRR w latach sześćdziesiątych, jest fakt, że są to na ogół wizyty oficjalne, odbywane na zaproszenie instytucji państwowych i pod nieustanną opieką powiązanych z

${ }^{258}$ Ş. Rado, op. cit., s. 12. 
partią komunistyczną przewodników i tłumaczy. Truizmem będzie stwierdzenie, że taka forma zwiedzania kraju była bardzo ułomna, albowiem oglądano wyłącznie to, co zaplanowano w programie i co przeznaczone było dla oczu obcokrajowców (İlhan Selçuk w Kazachstanie wymusza na swym przewodniku możliwość wejścia do starego, zniszczonego meczetu, w którym jedyny raz podczas swojej podróży spotyka osobę w obdartych ubraniach). Spośród tureckich reportażystów jedynie Samet Ağaoğlu zdaje się dostrzegać wynikające z tego ograniczenia reporterskiej niezależności - zaraz po przekroczeniu granicy tureckiej i wjeździe na teren Armeńskiej Socjalistycznej Republiki Radzieckiej poczuli wraz z żoną, że są nieustannie obserwowani. Ich samochód co kilkadziesiąt kilometrów był kontrolowany przez policję, a wpisane do paszportów pozwolenie na jazdę do Baku pozwalało wyłącznie na postój w celu zatankowania pojazdu i zjedzenia posiłku. Kiedy zbliżali się do Gandży, przed wjazdem do miasta zapytali młodego mężczyznę W samochodzie o restaurację, a ten poprowadził ich na miejsce. Zamiast jednak od razu wejść do środka, postanowili przejść się po mieście. Podczas fotografowania meczetu, zostali zatrzymani przez policjantów, którzy zapytali, dlaczego nie są teraz we wskazanej im restauracji. Samet Ağaoğlu opisuje więcej podobnych sytuacji, a cały jeden rozdział swojej książki poświęca organizacji o nazwie Intourist, będącej przedsiębiorstwem obsługi turystycznej, powiązanym ściśle z policją polityczną: „Jednakże zadaniem Intouristu nie jest wyłącznie obsługa turystyki. Jednocześnie jest to potężne oko państwa, obserwujące przyjeżdżających do Rosji obcokrajowców"259.

O ile Ağaoğlu zdaje sobie sprawę z konsekwencji wynikających z powiązań Intouristu z policją polityczną, o tyle pozostali tureccy reportażyści wydają się nie zwracać na to uwagi: są zadowoleni z opieki przewodników-tłumaczy i przekonani, że niezależnie od wszelkich okoliczności podróży ich spostrzeżenia są obiektywne i niezależne, a oni przekazują czytelnikom prawdę o ZSRR. Reportaże Metina Tokera tak zostały zapowiedziane przez redaktora naczelnego tygodnika „Akis” w 578 numerze z 17 lipca 1965 roku:

„Nasz reporter, który z niespotykaną dotychczas u żadnego dziennikarza swobodą pokonał w Rosji Sowieckiej 16 tysięcy kilometrów, zatrzymywał się tam, gdzie chciał, zwiedzał miejsca, które pragnął zwiedzić i rozmawiał z tymi obywatelami, z którymi chciał rozmawiać" 260 .

Wystarczy jednak uważnie przeczytać reportaże Tokera, by zorientować się, że w rzeczywistości nie był on tak niezależny, za jakiego chciał uchodzić. Dziennikarzowi i jego żonie nieustannie ktoś towarzyszył: przynajmniej jeden, a czasem dwóch tłumaczy oraz przedstawiciele Związku Dziennikarzy ZSRR, na zaproszenie którego przyjechał. Fundowano im bilety lotnicze, planowano trasę podróży, na lotnisko dowożono służbowymi pojazdami (kiedy w drodze na lotnisko w Moskwie zatrzymała ich milicja za przekroczenie prędkości, zostali natychmiast wypuszczeni po wyjaśnieniach jednego z tłumaczy i ,pojechali dalej z tą samą prędkością" ${ }^{261}$ ), w poszczególnych miastach witano i żegnano kwiatami, a raz nawet wstrzymano samolot lecący z Moskwy do Baku, gdy pomylone zostały godziny odlotu

\footnotetext{
${ }^{259}$ S. Ağaoğlu, Sovyet Rusya İmparatorluğu, Baha Matbaası, İstanbul 1967, s.160.

${ }^{260}$ M. Toker, op. cit., s.3.

${ }^{261}$ M. Toker, Dıș Geziler: Rusya, ,Akis” 1965, nr 582, s. 25.
} 
(zabawnie przedstawiona została historia o szukaniu właściwego samolotu na płycie lotniska: tłumacz pytał siedzących w samolotach pilotów, dokąd lecą). Podobnie zwiedzali inni reportażyści, zabierani przez swych przewodników w różne miejsca, np. Melih Cevdet Anday, Aziz Nesin i Yaşar Kemal pojechali do jakiegoś sowchozu „gdzieś daleko od Baku"262 (Anday nie wiedział nawet dokładnie gdzie, jedyne co umiał powiedzieć to, że droga mu się dłużyła), po którym zostali oprowadzeni. Analiza poszczególnych reportaży pokazuje znaczne podobieństwa: goście często zwiedzają te same miejsca, podają te same dane statystyczne, którymi są raczeni przez przewodników, a w kilku przypadkach korzystają z usług tych samych tłumaczy. Za najbardziej niezależnego można uznać Sameta Ağaoğlu, podróżującego po ZSRR własnym samochodem, ale nawet i on może pojechać do swej rodzinnej miejscowości w Karabachu wyłącznie w towarzystwie przedstawiciela Intouristu.

$\mathrm{W}$ takich warunkach raczej wątpliwe było osiągnięcie celu, jakim według deklaracji tureckich reportażystów miało być poznanie prawdy o komunizmie i o losie azerbejdżańskich współbraci pod rządami Sowietów.

\section{Poczucie wspólnoty kulturowej}

Poczucie turecko-azerbejdżańskiej wspólnoty kulturowej, wspomniane na początku tego artykułu, jest jednym $\mathrm{z}$ najbardziej wyeksponowanych elementów reportaży tureckich literatów, odwiedzających Azerbejdżan w latach sześćdziesiątych XX wieku. Poczucie to wzmocnione jeszcze zostaje przez specyfikę języka tureckiego. W terminologii tureckiej brak bowiem leksykalnego rozróżnienia na ,język turecki” (tur. Türk dili) i ,języki turkijskie” (tur. Türk dilleri, gdzie -ler jest sufiksem liczby mnogiej), funkcjonującego w wielu językach europejskich. Taka sama sytuacja była zresztą do niedawna obecna w polszczyźnie, gdzie podobieństwo określeń ,języki tureckie” i ,język turecki” rodziło pomieszanie terminologiczne - dopiero od lat dziewięćdziesiątych XX wieku za sprawą Henryka Jankowskiego coraz bardziej powszechne staje się użycie nazwy ,języki turkijskie"263. Tureccy reportażyści określają więc często mieszkańców Azerbejdżanu Turkami (tur. Türkler $^{264}$ ), z ewentualnym uszczegółowieniem: Turcy z Azerbejdżanu / Turcy Azerbejdżańscy (tur. Azerbaycan Türkleri ${ }^{265}$; Azerbaycanll Türkler ${ }^{266}$ ) lub Turcy Azerscy (tur. Azeri Türkleri ${ }^{267}$ ). Oprócz tego funkcjonują oczywiście określenia bardziej neutralne, jak: Azerbejdżanie (tur. Azerbaycanlılar ${ }^{268}$; dosł. pochodzący z Azerbejdżanu) oraz Azerowie (tur. Azeriler ${ }^{269}$ ). Należałoby oczywiście przeprowadzić bardziej szczegółową analizę onomastyczną, uwzględniającą ilość zastosowań poszczególnych określeń, natomiast lektura tekstów reportażowych wskazuje na dość przypadkowy dobór słownictwa przez

\footnotetext{
${ }^{262}$ M. C. Anday, Sovyet Rusya, Azerbaycan, Özbekistan, Bulgaristan, Macaristan, Gerçek Yayınları, İstanbul 1965 , s. 56.

${ }^{263}$ H. Jankowski, Gramatyka języka krymskotatarskiego, Wydawnictwo Naukowe UAM, Poznań 1992, s. 1.

${ }^{264}$ S. Ağaoğlu, op. cit., s. 23; İ. Selçuk, Uzak Komşu Rusyadan Gezi Notları, Köprü Yayınları, İstanbul 1967, s. 79.

${ }^{265}$ Ş. Rado, op. cit., s. 67. Analogicznie do tego pojawia się określenie Turcy z Turcji (tur. Türkiye Türkleri). Zob. Ş. Rado, op. cit., s. 66.

${ }^{266}$ M. Turgut, Taşkent'e Doğru. Rusya Notları, Ajans - Türk Matbaacılık Sanayı, Ankara 1969, s. 105.

${ }^{267}$ M. Turgut, op. cit., s. 107; S. Ağaoğlu, op. cit., s. 24; Ş. Rado, op. cit., s. 63.

${ }^{268}$ M. Turgut, op. cit., s. 111; Ş. Rado, op. cit., s. 64; M. Anday, op. cit., s. 48.

${ }^{269}$ M Turgut, op. cit., s. 107; S. Ağaoğlu, op. cit., s. 25, 27, 29, 32; İ. Selçuk, op. cit., s. 84.
} 
poszczególnych autorów. Najlepiej widać to na przykładzie Sameta Ağaoğlu, który oburzał się na dokonywane przez Rosjan próby oderwania Azerbejdżan od ich tureckich korzeni i wzbudzenia w nich uczuć nacjonalistycznych, co przejawiać miało się między innymi w „głoszeniu, że nie są Turkami, tylko Azerami”"270, sam zaś niejednokrotnie używał właśnie nazwy Azerowie ${ }^{271}$.

Łatwy do zrozumienia język to według Turków pierwsza i najważniejsza podwalina wspólnoty kulturowej. Reportażyści tureccy, którzy najczęściej docierali do Baku bezpośrednio po wizycie w Moskwie, czuli się tam jak u siebie w domu. İlhan Selçuk przykładowo westchnął z ulgą, że wreszcie znalazł się w tureckim (turkijskim) kraju ${ }^{272}$. Turcy mogli wreszcie odprawić tłumaczy języka rosyjskiego (choć ci na ogół i tak im towarzyszyli, a dodatkowo przydzielano do pomocy nowych przewodników mówiących po azerbejdżańsku) i porozumiewać się po turecku. Obowiązkowy w reportażach wydaje się, krótszy bądź dłuższy, passus na temat różnic (dziś powiedzielibyśmy false friends) w tureckim i azerbejdżańskim, mający na celu rozbawienie czytelnika i przykucie jego uwagi. Za przykład niech posłuży fragment $\mathrm{z}$ artykułu Metina Tokera:

„Turecki azerski jest trochę inny od naszego tureckiego. Używają słów w nieco innym znaczeniu, ale łatwo je zrozumieć w kontekście całego zdania. Mówią na przykład „poradzę się po turecku” (Türkçe danışırım), co znaczy „rozmawiam po turecku” (Türkçe konuşurum). Mówią „wypadnijmy z promu” (vapurdan düşelim), a to znaczy „wysiądźmy z promu” (vapurdan inelim). Mówią „schowaj się” (sakla), co znaczy „stój” (dur). (...) Ale nas najbardziej rozbawiło określenie ,łódka podwodna” (su altı kayığl), stosowane na „okręt podwodny” (denizaltı)",273.

Melih Cevdet Anday, podając bardzo podobne przykłady, wykorzystał je do żartów w rodzaju: „Jeśli mieszkaniec Baku powie wam, że jadąc do was wypadł z autobusu, nie próbujcie w żadnym wypadku życzyć mu zdrowia i dopytywać o to, czy nic mu się nie stało! ${ }^{274, "}$. Zwrócił on również uwagę na różnice $\mathrm{w}$ akcencie i nazywając azerbejdżański dialektem (tur. Azer lehçesi) ${ }^{275}$ stwierdził, że po kilku dniach nie miał najmniejszych problemów ze zrozumieniem rozmówców. Şevket Rado z kolei uznał, że azerbejdżański jest bardzo podobny do tureckiego używanego przez mieszkańców Erzurum, miasta w północnowschodniej Turcji. Tureccy reportażyści ubolewali jedynie nad odmiennością alfabetu, a Metin Toker słusznie zauważył, że gdyby nie cyrylica, wprowadzona przez Rosjan, pragnących oderwać Azerbejdżan od zachodnioeuropejskiego (w tym tureckiego) kręgu kulturowego, poczucie wspólnoty kulturowej byłoby jeszcze większe.

\footnotetext{
${ }^{270}$ S. Ağaoğlu, op. cit., s. 28. Słowo „Azer” (tur. Azeri) thumaczone jest w słowniku Tureckiego Towarzystwa Językowego (TDK) przy pomocy synonimu Turek z Azerbejdżanu/Turek Azerbejdżański (tur. Azerbaycan Türkü) i jest pochodzenia perskiego. Zob. https://sozluk.gov.tr/

${ }^{271}$ S. Ağaoğlu, op. cit., s. 25, 27, 29, 32.

${ }^{272}$ İ. Selçuk, op. cit., s. 77.

${ }^{273}$ M. Toker, op. cit., nr 582, s. 26.

${ }^{274}$ M.C. Anday, op.cit., s. 48.

${ }^{275}$ Ibidem, s. 48.
} 
Znamienna jest również dyskusja, jaką İlhan Selçuk przeprowadził z azerbejdżańskimi intelektualistami i przedstawicielami świata nauki (jedną $\mathrm{z}$ obowiązkowych wizyt, zaplanowanych dla tureckich reportażystów, była wizyta w Akademii Nauk i na uniwersytecie oraz w Związku Pisarzy Azerbejdżańskich). Początkowo nie mógł on zrozumieć, dlaczego azerbejdżańska elita intelektualna rezygnuje z języka azerbejdżańskiego na rzecz rosyjskiego, skoro grozi to regresją języka ojczystego, a język stanowi przecież o istnieniu narodu. Selçuk dał się dość szybko przekonać argumentom o potrzebie wspólnego języka nauki i administracji, podobnie jak inny zwolennik socjalizmu, Melih Cevdet Anday. Tymczasem pisarze o centroprawicowych poglądach nie byli skłonni ulegać tym propagandowym tłumaczeniom, a szczególnie bolesny był dla nich fakt, że także wśród prostych obywateli zaczyna szerzyć się zwyczaj mówienia na co dzień po rosyjsku lub wtrącania rosyjskich słów w prowadzonej po azerbejdżańsku rozmowie. Samet Ağaoğlu stwierdził, że po przyjeździe do Baku miał nieraz kłopot z rozróżnieniem języka, którym posługiwali się jego rozmówcy, ponieważ w powszechnym użyciu jest pidżyn, będący mieszanką rosyjskiego i azerbejdżańskiego. Ağaoğlu zauważył ze smutkiem: „Wygląda na to, że turecki [azerbejdżański - dop. SF] traci swe znaczenie w Baku oraz całym Azerbejdżanie i szybko ustępuje pola rosyjskiemu",276.

Innym elementem budującym turecko-azerbejdżańską wspólnotę kulturową jest pamięć o wspólnej tradycji literackiej, przede wszystkim tej z czasów przynależności obu narodów do jednego organizmu państwowego - jej symbolem jest Fuzuli, szesnastowieczny poeta azerskiego pochodzenia, który po zdobyciu przez Sulejmana Wspaniałego Bagdadu, zasłynął jako jeden z najwybitniejszych poetów osmańskich. W rzeczywistości Azerowie nie spędzili zbyt wiele czasu pod osmańską egidą, gdyż XVI i XVII wiek upłynął pod znakiem wojen safawidzko-osmańskich i przechodzenia terenów dzisiejszego Azerbejdżanu z rąk do rąk, aż ostatecznie przypadły one Persji, a następnie dostały się w strefę wpływów rosyjskich. Tureccy reportażyści, niezrażeni nieścisłościami historycznymi, przywoływali chętnie jeszcze jeden przykład turecko-azerbejdżańskiej wspólnoty literackiej: Nizamiego, dwunastowiecznego poetę perskiego pochodzącego z Gandży. W zasadzie obaj Ci poeci są częścią szerszej tradycji literackiej, którą można nazwać bliskowschodnią, a przyczynkiem do przywołania tych właśnie postaci były ich pomniki w Baku. Widok pomników budził w Turkach rodzaj zawstydzenia, co doskonale widać w słowach Şevketa Rado:

„Czy w tak ogromnym kraju, jakim jest Turcja, na placach widać posągi naszych wspaniałych poetów? Nie mamy niczego, prócz kilku popiersi gdzieś na uboczu. Tymczasem w Baku naprzeciwko Teatru Dramatycznego znajduje się ośmiometrowy posąg tureckiego poety Fuzuliego. Inny plac zdobi jeszcze potężniejszy posąg Nizamiego, poety z Gandży"277.

Tureckich reportażystów zachwycała pamięć o wielkich poetach, o których „,nowe pokolenie w Turcji powoli zapomina"278. Şevketowi Rado nie podobało się jedynie upolitycznianie ich twórczości. Opisał, jak kupił sobie w Baku piękne, ilustrowane wydanie

\footnotetext{
${ }^{276}$ S. Ağaoğlu, op. cit., s. 24.

${ }^{277}$ S.. Rado, op. cit., s. 67.

${ }^{278}$ M. Turgut, op. cit., s, 106.
} 
Layli i Medżnuna Fuzuliego w alfabecie arabskim, a we wstępie ze zgrozą wyczytał, że poeta był komunistą. Turkom podobało się również, że w Azerbejdżanie wiedza o współczesnej literaturze tureckiej była całkiem spora, choć Samet Ağaoğlu narzekał, że znani są tylko pisarze o lewicowych poglądach.

Kwestia wspólnoty religijnej, w przeciwieństwie do wspólnoty językowej czy literackiej, jest praktycznie nieporuszana $\mathrm{w}$ reportażach, co ma zapewne związek z wysokim poziomem laicyzacji obu państw w latach sześćdziesiątych. Pisarze tureccy, zwłaszcza ci lewicujący, z zadowoleniem konstatowali tylko, że kobiety w Azerbejdżanie nie zasłaniają włosów, w przeciwieństwie do niektórych Turczynek, co potraktowali jako oznakę zacofania religijnego, której nie udało się zupełnie wyplenić w republikańskiej Turcji.

Ściśle powiązana $\mathrm{z}$ poczuciem wspólnoty kulturowej jest pamięć o idei Wielkiego Turanu, wciąż żywa w tureckich reportażach. Wprawdzie panturanizm (zwany też panturkizmem), jako pomysł zjednoczenia wszystkich ludów turkijskich w ramach jednego wielkiego państwa, przeżywał lata świetności na przełomie XIX i XX wieku, jednak można powiedzieć, że Turcy jeszcze w latach sześćdziesiątych snuli mrzonki na temat Wielkiego Turanu - określenie to pojawia się w każdym prawie reportażu. Jednocześnie mieli oni świadomość, że w czasach im współczesnych jest to utopia. İlhan Selçuk zauważył, że winę za taki stan rzeczy ponosi Turcja, która po rozpadzie imperium osmańskiego nie była zainteresowana losem „bratnich” narodów, a na obecnym etapie rozwoju (Azerbejdżan postrzegał jako kraj lepiej rozwinięty ekonomicznie niż Turcja) elitom azerbejdżańskim nie zależy na kultywowaniu turkijskiej tożsamości.

\section{Niezależny Azerbejdżan a poparcie dla socjalizmu}

Zdaniem wszystkich tureckich reportażystów Azerbejdżan lat sześćdziesiątych to kraj lepiej rozwinięty ekonomicznie niż Turcja. Wrażenie to pojawia się tuż po wylądowaniu w Baku, podczas drogi z lotniska do centrum, która wiodła przez pola naftowe, a powszechnym widokiem był „las wież szybów naftowych"279. Turcy zaskoczeni ogromem pól naftowych konstatowali brak obsługi, co świadczyć miało o wysokim poziomie zmechanizowania wydobycia. Mieli oni okazję zachwycać się nowoczesnymi rozwiązaniami technologicznymi również podczas obowiązkowych wizyt $\mathrm{w}$ rafineriach i fabrykach, po których często zasypywali czytelnika danymi statystycznymi i liczbami, dotyczącymi wydobycia i produkcji. Korzyści wypływające z upaństwowienia gospodarki były zaś prezentowane gościom podczas odwiedzin w sowchozach, którymi zachwycali się szczególnie pisarze lewicujący, np. Melih Cevdet Anday uwierzył we wszystko, co usłyszał od młodego, energicznego i kompetentnie wyglądający dyrektora sowchozu, toteż chwalił planowanie, system podziału zarobków, system motywacji finansowych czy możliwość kolektywnego zakupu maszyn, na które nie pozwoliłby sobie sam jeden rolnik itp. Tureccy reportażyści zwracali również uwagę na to, że udział kobiet w życiu publicznym i zawodowym w Azerbejdżanie był znacznie wyższy niż w Turcji. Zauważali obecność kobiet we wszystkich zawodach - od pracownika naukowego po ochroniarza $\mathrm{w}$ fabryce - co z kolei było zasługą rozbudowanego systemu żłobków i przedszkoli.

${ }^{279}$ M.C. Anday, op. cit., s. 46. 
Wszystko to miało sprawiać, zdaniem większości reportażystów, że poziom życia w Azerbejdżanie, a tym samym i zadowolenie mieszkańców, były wyższe niż w Turcji. Oczywiście Turcy wyciągali te wnioski na podstawie opinii swych rozmówców (przede wszystkim thumaczy i przewodników oraz osób, do których prowadzeni byli przez swych opiekunów), a także na podstawie własnych obserwacji poczynionych we wzorcowych fabrykach i sowchozach, po których ich oprowadzano. Niemały wpływ na tę opinię miały wygody, których sami doświadczali: komfortowe pokoje $\mathrm{w}$ hotelach, ciepła woda w łazienkach, restauracje $\mathrm{z}$ widokiem na morze, wieczorne dansingi zakrapiane obficie wódką i okraszane kawiorem.

Charakterystyczne jest, że opinie o szczęśliwym i wygodnym życiu, jakie wiodą mieszkańcy Azerbejdżanu, powtarzane były nie tylko przez pisarzy otwarcie popierających lewicowe ideologie (wśród autorów wybranych do analizy jest ich dwóch: Melih Cevdet Anday oraz İlhan Selçuk), których nie trzeba przekonywać, że socjalizm jest najlepszym możliwym systemem, ale również pisarze o centroprawicowych poglądach. Wzruszali się oni, jak Şevket Rado, gorącym powitaniem, jakie zgotowali im Azerbejdżanie, ustawiając się wzdłuż dwudziestoczterokilometrowej drogi z lotniska do centrum Baku. Spoglądając ze łzami w oczach na wiwatujących i machających im radośnie mieszkańców, Şevket Rado uwierzył w spontaniczność tych gestów i oddolną organizację powitania: „Później dowiedzieliśmy się, że ani gazety ani radio nie podały daty i godziny przyjazdu do Baku premiera Süleymana Demirela wraz z turecką delegacją (...) ${ }^{, 280}$. Nieco więcej wątpliwości miał Mehmet Turgut, witany (podobnie jak inni) na lotnisku przez wiwatujący tłum osób, wymachujących kwiatami: „Całe to zachowanie ludzi budzi wątpliwości, gdyż jest jakby wyuczone, nieco sztuczne i wymuszone" ${ }^{281}$. To stwierdzenie nie przeszkodziło mu jednak później w przyjmowaniu kwiatów i wzruszaniu się oznakami sympatii dla tureckiej delegacji. Metin Toker, podejrzliwy względem przekazywanych mu przez przewodników informacji, zażyczył sobie z kolei, by po zwiedzeniu jednej z fabryk w okolicach Baku, wejść do jakiegoś robotniczego mieszkania:

„To było małe, dwupokojowe mieszkanie. Przebywały w nim cztery osoby: małżeństwo, siostra żony i ojciec męża. W obu pokojach stały po dwa łóżka. Kuchnia była bardzo prosta. Na środku stał stół. Tam jadali posiłki. Całości dopełniał mały hol i podobnej wielkości łazienka. Ale w domu było radio, lodówka, telewizor i kuchenka gazowa"282.

W innych zwiedzanych miastach ZSRR Toker miał podobne życzenie, a odwiedzając domy miejscowych, za oznakę dobrobytu brał dostęp do nowinek technologicznych. Nieco mniej łatwowierny okazał się Samet Ağaoğlu, który rozumiał, że „sowiecka propaganda

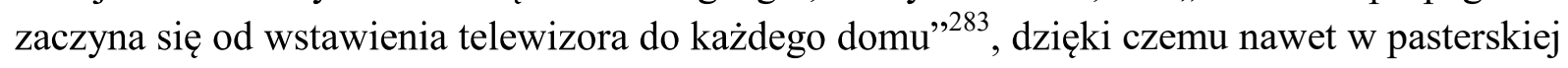
szopie rozbrzmiewa „głos Moskwy”. Szczególnie dały mu do myślenia trudności, jakie napotkał, chcąc spotkać się ze swoimi krewnymi w Baku. Niby oficjalnie nikt go do tego nie

\footnotetext{
${ }^{280}$ Ş. Rado, op. cit., s. 64.

${ }^{281}$ M. Turgut, op. cit., s. 5.

${ }^{282}$ M. Toker, op. cit., nr 583, s. 24.

${ }^{283}$ S. Ağaoğlu, op. cit., s. 152.
} 
zniechęcał, ale sami krewni wymyślali liczne preteksty, by do spotkania nie doszło. Kiedy już udało się zorganizować spotkanie w hotelowym lobby, twierdzili, że mają pozwolenie na wyjście z pracy tylko na godzinę i wszyscy z niepokojem spoglądali na zegarki. Pytani przez Sameta Ağaoğlu, jak im się żyje, odpowiadali zgodnie: „Jest nam dobrze, bardzo dobrze. Mamy pieniądze, mamy pracę!" 284 . Ağaoğlu domyślił się, że wolą oni, by nikt ich z nim nie zobaczył. Nie uwierzył też w zapewnienia o wygodnym życiu.

Kwestia uzyskania przez Azerbejdżan politycznej niezależności praktycznie nie jest poruszana $w$ tureckich reportażach. Nie mówią o niej, co oczywiste, rozmówcy reportażystów, a i Turcy zdają się akceptować istniejącą sytuację i nie frapuje ich kwestia uniezależnienia Azerbejdżanu od ZSRR. Niemała w tym rola propagandy, o mechanizmach której Samet Ağaoğlu napisał kilkustronicowy rozdział w swej książce. Oczywiście Turcy o lewicowych poglądach bez sceptycyzmu podchodzili do propagandowych treści. Jak zauważył Jakub Mirowski w swej pracy magisterskiej analizującej reportaże Andaya i Selçuka: „Obaj autorzy w pełni zgadzają się, że funkcjonowanie republik zamieszkanych przez ludy tureckie w ramach Związku Radzieckiego pozwoliło im na dotarcie do cywilizowanego etapu rozwoju"285. İlhan Selçuk przytoczył swoją rozmowę z jednym z profesorów, którego zapytał o kwestię wyzyskiwania Azji Środkowej przez komunistów, analogicznego do tego $\mathrm{z}$ czasów carskich. Jako przykład podał fakt dzielenia się przez Azerbejdżan przychodami z wydobycia ropy naftowej z innymi, biedniejszymi republikami. Wyraźnie zaskoczony tym pytaniem profesor wyjaśnił, że nikt w Azerbejdżanie nie traktuje tego jak eksploatację, gdyż kolektywizm jest podstawą „braterskiej” ideologii komunistycznej. Selçuk bardzo szybko się z nim zgodził. Tymczasem niezaangażowany politycznie Şevket Rado był już nieco ostrożniejszy z szafowaniem opinii w tym temacie. On również uznał, że ,z pewnością komunizm odniósł sukces, gdy przed pięćdziesięciu laty odziano głodny i nagi lud"286, ale później jego ideały nie zostały zrealizowane, a praktyka nie zgadza się z teorią, gdyż klasa rządząca wiedzie bogate i wygodne życie kosztem pozostałych obywateli. Mehmet Turgut poszedł jeszcze dalej, zarzucając władzom ZSRR eksploatację turkijskich republik, podobną do procesów kolonizacyjnych. Na kilku stronach swej książki wykrzykiwał z oburzeniem, że prości mieszkańcy Azerbejdżanu są tak samo biedni i głodni, jak przed rewolucją, a dodatkowo zabrano im wolność: „Bilans pięćdziesięciu lat: po pięć, dziesięć wieżowców w każdym mieście i coraz więcej miliardów spływających rokrocznie do skarbu Związku Radzieckiego,"287.

Łatwo zauważyć, że odpowiedź na pytanie, jak żyje się tureckim pobratymcom w ustroju socjalistycznym, zależy w dużej mierze od poglądów politycznych autora. Pisarze lewicujący (Melih Cevdet Anday i İlhan Selçuk) w pełni popierali socjalizm, postulując wprowadzenie tego systemu również w Turcji, gdzie jak zauważył İlhan Selçuk, komuniści przedstawiani byli najczęściej jak potwory czy upiory ${ }^{288}$. Postawa taka przestaje dziwić, jeśli zwrócimy uwagę na to, że lata sześćdziesiąte były okresem największego poparcia dla

\footnotetext{
${ }^{284}$ Ibidem, s. 32.

${ }^{285}$ J. Mirowski, Sierp, młot i półksiężyc. Analiza tureckich reportaży z ZSRR, Kraków 2019, s. 33.

${ }^{286}$ Ş. Rado, op. cit., s. 83-84.

${ }^{287}$ M. Turgut, op. cit., s. 113.

288 İ. Selçuk, op. cit., s. 32.
} 
socjalizmu w wydaniu radzieckim, nie tylko w Turcji ${ }^{289}$, ale również na Zachodzie ${ }^{290}$. Tureckich socjalistów tak sparodiował Mehmet Turgut: „ze szklaneczką whisky w ręku gryzmolą jakieś poematy o wstecznictwie, uśmiechając się kapryśnie i drwiąco spod sumiastych wąsów à la Stalin" "291. Mehmet Turgut zaprezentował niewątpliwie najbardziej kategoryczny brak poparcia dla socjalizmu, jako jedyny wypowiadając się otwarcie na temat ograniczenia wolności mieszkańców Azerbejdżanu. O braku wolności słowa i poglądów napomykał również Samet Ağaoğlu, natomiast Metin Turan i Şevket Rado dali się dość łatwo przekonać o wielostronnym dobrobycie panującym w Azerbejdżanie. Wszyscy reportażyści, bez wyjątku, nie demonizowali jednak ZSRR i mimo silnego poczucia wspólnoty kulturowej z mieszkańcami Azerbejdżanu, nie widzieli potrzeby walki, choćby na kartach literatury, o niezależność tego kraju.

\section{Streszczenie:}

W artykule przeanalizowane zostały reportaże sześciu tureckich literatów (Melih Cevdet Anday, Metin Toker, Samet Ağaoğlu, İlhan Selçuk, Şevket Rado, Mehmet Turgut), którzy w latach sześćdziesiątych XX wieku, korzystając $\mathrm{z}$ otwarcia się ZSRR na świat po śmierci Stalina, odwiedzili Azerbejdżan. Celem ich podróży miało być poznanie prawdy o komunizmie i o losie azerbejdżańskich współbraci pod rządami Sowietów. Jak wykazała analiza reportaży, okoliczności ich podróży (tj. krótki pobyt, podróż odbyta najczęściej na zaproszenie władz państwowych, zwiedzanie $\mathrm{w}$ towarzystwie powiązanych $\mathrm{z}$ partią komunistyczną tłumaczy i przewodników) sprawiły, że osiągnięcie tego celu nie było do końca możliwe. Wnioski reportażystów zależały często od ich orientacji politycznej: pisarze lewicujący w pełni popierali socjalizm, postulując jego wprowadzenie również w Turcji, podczas gdy pisarze o poglądach prawicowych byli znacznie bardziej sceptyczni. Wszyscy jednak zostali przekonani o panującym w Azerbejdżanie dobrobycie ekonomicznym i mimo silnego poczucia wspólnoty kulturowej z mieszkańcami Azerbejdżanu, nie widzieli potrzeby walki o niezależność tego kraju.

\section{Słowa kluczowe:}

reportaż, Azerbejdżan, literatura turecka, stosunki turecko-azerbejdżańskie

\section{Key words:}

reportage, Azerbaijan, Turkish literature, Turkish-Azerbaijani relations

\footnotetext{
289 W Turcji nastroje lewicowe wśród intelektualistów wzmacniane były w opozycji do skrajnie nacjonalistycznego, współpracującego ze Stanami Zjednoczonymi rządu Adnana Menderesa i jego Partii Demokratycznej. Po pogromach ludności greckiej, ormiańskiej, żydowskiej i chrześcijańskiej we wrześniu 1955 roku nastąpiło zaostrzenie konfliktu między rządem a turecką inteligencją, które zelżało dopiero po przewrocie wojskowym z 27 maja 1960 roku.

${ }^{290}$ Dość wspomnieć kilka nazwisk: Jean Paul-Sartre (był w ZSRR w trakcie podróży Andaya), Simone de Beauvoir, Louis Aragon, Albert Camus, Richard Wright. Por. J. Mirowski, op. cit., s. 17-18.

${ }^{291}$ M. Turgut, op. cit., 113-114.
} 


\section{Bibliografia:}

1. Z. Aliyeva, Türkiye-Azerbaycan Edebi Illişkilerinde Selef ve Halef Yazarlar: Mirza Fethali Ahundzade ve Anar Rızayev, „Atatürk Üniversitesi Sosyal Bilimler Enstitüsü Dergisi" 2015, nr 19 (1), s. 215-225.

2. S. Ağaoğlu, Sovyet Rusya Imparatorluğu, Baha Matbaası, İstanbul 1967.

3. M. C. Anday, Sovyet Rusya, Azerbaycan, Özbekistan, Bulgaristan, Macaristan, Gerçek Yayınları, İstanbul 1965.

4. B. Asıltürk, Edebiyatın Kaynă̆ı Olarak Seyahatnameler, „Turkish Studies” 2009, nr 4, s. 911-995.

5. H. Jankowski, Gramatyka języka krymskotatarskiego, Wydawnictwo Naukowe UAM, Poznań 1992.

6. N. Nagıyeva, 1990'dan Günümüze Türkiye ve Azerbaycan Edebiyatlarının Karşılıklı Etkileşimi, İstanbul 2017.

7. Aziz Nesin, Yazar, Halk, İktidar, tł. Mustafa Y1lmaz, „Sözcükler” 2012, nr 39 (9/10).

8. J. Mirowski, Sierp, młot i półksiężyc. Analiza tureckich reportaży z ZSRR, Kraków 2019. [niepublikowana praca magisterska]

9. Ş. Rado, 50. Yllında Sovyet Rusya, Doğan Kardeş Matbaacılık, İstanbul 1968.

10. İ. Selçuk, Uzak Komşu Rusyadan Gezi Notları, Köprü Yayınları, İstanbul 1967.

11. M. Toker, Dış Geziler: Rusya, „Akis” 1965, nr 578, s. 4-9.

12. M. Toker, Dış Geziler: Rusya, „Akis” 1965, nr 582, s. 23-26.

13. M. Toker, Dış Geziler: Rusya, „Akis” 1965, nr 583, s. 23-26.

14. M. Toker, Dış Geziler: Rusya, „Akis” 1965, nr 584, s. 24-27.

15. M. Turgut, Taşkent'e Doğru. Rusya Notları, Ajans - Türk Matbaacılık Sanayı, Ankara 1969.

16. słownik turecki TDK, za: https://sozluk.gov.tr/ (25.03.2020) 